\section{In memoriam of Peppe Morabito}

Firenze, April 16, 1964 - Castelletto Ticino, July 12, 2017

"Lightly we passed on Earth" is the title of a novel by Sergio Atzeni, published in 1996, one year after his untimely death by drowning in the Tyrrhenian sea. The author is referring to the levity of water. «Lightly we passed on Earth".... "like the water that flows, jumps from the hollow spring, winds between mosses and ferns up to the roots of almond and cork trees or rolls over the stones from mountains and hills toward the plain, from stream to river, slowing down on the way to the swamps and the sea, transmuted by the sun in steam, in clouds moved by the wind, and in blissful rain..."

Giuseppe, Peppe for family and friends, loved the water with which he felt in perfect harmony and in which he found comfort and peace also through the worsening of his illness. The attraction for water became scientific passion when Peppe started his Degree thesis under the supervision of Delio Ruggiu, a prominent Italian limnologist. At the Pallanza Istituto Idrobiologico, Peppe found a place celebrated for its pioneering studies on lakes, their evolution, the importance of long term data, the significance and limitation of trophic indicators, the value of comparative limnology. To enter the Pallanza Istituto meant to immerse in the forefront of the international scientific debate on aquatic ecology having as colleagues of your own supervisor the Reynolds, the Harris, the Vollenweider...

In the silence broken only by the ticking of Pierisa's counter, to whom was confided the phytoplankton microscopic analyses and the field data compilation, lakes were investigated as ecosystems. In primis, Lago Maggiore where primary production measurements were pioneered in the 1950s by Rich Vollenweider during his stay at the Istituto. Then Lago d'Orta, so fragile, so needy of attention. Lago d'Orta was indeed Peppe's research topic for his Degree thesis. At once, Peppe demonstrated rare capacities of synthesis, critical thinking, associated with a gift for clear and effective writing. Delio could only add few comments to Peppe's masterful presentation.

In the second-floor laboratory, open to the majestic view of Lago Maggiore, student and supervisor built a scientific partnership that would produce a wealth of substantial contributions to phytoplankton ecology. In particular, Peppe significantly contributed to the morpho-functional characterization of phytoplankton of subalpine deep lakes. This step was crucial for comparative limnology to understand structure and function of

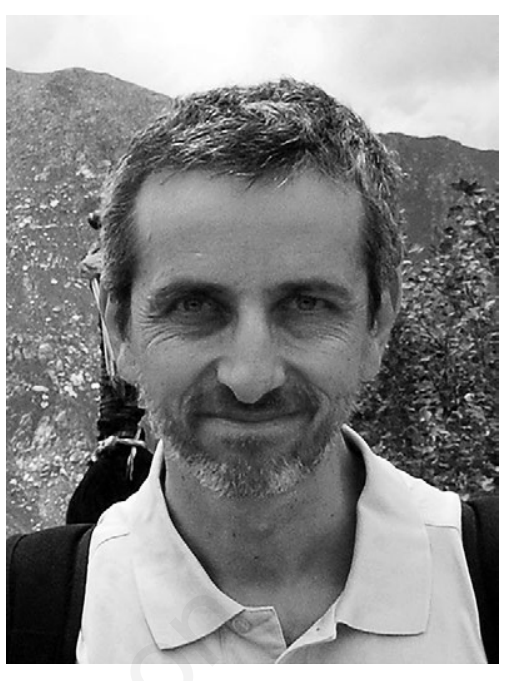

aquatic ecosystems under natural conditions, stress, and recovery. Many colleagues have passed through this laboratory over the years to discuss of phytoplankton ecology: Letizia Garibaldi, Nico Salmaso, Renata Trevisan, Luigi Naselli Flores, Marco Simona, Fabio Buzzi, Giulio Di Leo; Laurence Carvalho, Antonella Lugliè, Nicola Sechi, just to cite a few. During her visits in Italy, Antonella Cattaneo always visited the laboratory to discuss science and collaborate on studies of Lago d'Orta and Lago di Candia. In the context of an Italy-Quebec scientific cooperation program, Peppe was invited by the Biology Department of Université de Montréal to collaborate with Antonella and her colleague Bernadette Pinel-Alloul in a comparative study of methods and biota of these two very different regions.

Peppe was a mentor to several students for their Degree or $\mathrm{PhD}$ theses. Several of these students became in turn successful scientists and collaborators as Alessandro Oggioni with whom Peppe shared the interest in the use of long-term data and historical series and the fine tuning of modern environmental technologies. Moreover, Peppe collaborated with Martina Austoni profiting of her expertise on phytoplankton taxonomy and photographic documentation of algal blooms and with Tommaso Sforzi through their effort to organize and archive phytoplankton monitoring data collected by Environmental agencies in several Italian lakes.

Alessandra Pugnetti, that preceded Peppe as a research staff of the CNR-Istituto Italiano di Idrobiologia, shared with him many scientific discussions and research campaigns. With Alessandra, Peppe extended his research to the phytoplankton of high altitude alpine lakes, crucial habitats for studying the effects of acid rain and 
contaminant long-distance transport on lake ecosystems. This research resulted in a seminal contribution to long term studies by implementing investigations started by Rina Monti Stella in the 1880s. Always with Alessandra, Peppe addressed the debate over the mechanisms at the base of the decoupling between primary production, i.e. potential growth, and real growth They highlighted that process variables responded better than standing variables, as chlorophyll and biomass, to nutrient reduction and oligotrophication, making worldwide famous the example of Lago Maggiore. When Alessandra later moved to oceanography, their fruitful scientific partnership continued in the LTER (Long-Term Ecological Research Network) context with outstanding, some very recent, contributions to comparative studies in freshwater and marine ecosystems on development of advanced instrumentation and of theories on the role of climate and anthropogenic variables.

Peppe's passion for field and laboratory studies and implementation of innovative technologies found a suitable application in a team research on Lago di Candia, a shallow lake in the Canavese region of Piedmont. The studies on this lake aimed at controlling the eutrophication through the integrated management of the lake watershed and its biota. Lago di Candia was thus offering the possibility to test the applicability of biomanipulation to lake remediation while assessing the relative importance of biotic and abiotic variables and the validity of the Size Efficiency Hypothesis of Brooks \& Dodson. Working on this case study, that became the topic of his $\mathrm{PhD}$ thesis at the Università di Parma, Peppe had the opportunity to express his originality, combining classic phytoplankton methods with cutting-edge laboratory tools and in situ incubations. He also showed a clear and singularly elegant writing style in the presentation and discussion of the findings. The thesis earned him, infra alia, a prize that he received thanking with his trademark modesty his teachers (among whom Ireneo Ferrari) and fellow students for their contribution to his research.

For me, Lago di Candia remains linked to a personal souvenir of Peppe's generosity and kindness. In order to study zooplankton diel vertical migration (DVM), we had planned an intensive research effort with samplings scheduled every $4 \mathrm{~h}$, day and night. Because each sampling lasted $2 \mathrm{~h}$, only $2 \mathrm{~h}$ remained between successive outings. We were three researchers: Peppe, Waleed Hamza (a PhD student), and myself. Waleed and I collected the zooplankton in the boat while Peppe was processing the samples in the base-camp laboratory. At 2 AM, we had concluded a sampling and the next one was planned for 4 PM. We were sleeping in sleeping bags under an awning close to the lake and I was suffering of a convulsive gravidic cough. Fearing of being overcome by exhaustion, I asked my colleagues to my colleagues to rouse me, if still asleep. In the morning, I woke up to realize that the 4 AM sampling had been completed by Peppe and Walid while I was fast asleep. I will never forget the brightness of Peppe's smile when I thanked him. Alessandra, Peppe and Waleed went to a Congress on DMV in Amsterdam when my son Dario was just one month old. They brought me back a wonderful poster with the cladoceran drawings from Sars' book. That poster with its touching inscription is still with me.

The multi-faceted expertise of Peppe on phytoplankton (relationships between structure and function, development of algal indicator species, succession, long-term trends under trophic and climatic stresses, ecophysiology) was precious in the implementation of the Water Framework Directive, in which the quality of freshwater bodies is based on ecological criteria, often centered on phytoplankton. This approach, carried out from 2004 to 2013, brought Peppe to oversee several large scale European projects as "Local hydro-morphology, habitat and River Basin Management Plans (RMBS): New measures to improve ecological quality in South European rivers his and lakes (LIFE+ INHABIT); Water Bodies in Europe: Integrative Systems to assess Ecological Status and Recovery (EU FP-7: WISER); "Evaluating the Impacts of Global Change on European Freshwater Ecosystems (EU FP-6: Euro-limpacs).

Scientific interest was combined in Peppe with a strong civic commitment. He believed that being a scientist should not be limited to interaction with colleagues in national and international meetings and discussion groups but should also entail the responsibility of educating the public to the problems faced by inland waters. In a slide prepared for one of his several educational presentations, he warned: "Lakes represent the largest reserve of immediately available freshwater on the planet; this reserve is sufficient but NOT abundant... ". Furthermore, he wrote in the announcement of the AIOL (Associazione italiana di Oceanologia e Limnologia) Congress organized in Pallanza: "To foster the transfer of scientific findings to society, administrators at the local, regional, and national level should be invited to attend the Congress. Moreover, a section of the Congress should be open to the public at large (especially the schools) to encourage interaction with the scientists to promote and popularize the knowledge about protection and management of water resources".

Societal commitment, profound expertise in phytoplankton spatial and temporal dynamics, and appeal for modern oceanographic technologies led Peppe to a novel 
research, He dreamed of realizing in lakes, starting from Maggiore and Orta, the experience of ships of opportunity, collecting in real time relevant environmental data by means of sensors deployed on moving vessels. The project SAILING (SENSOR BASED Assessment of InLake Processes and water quality: scientific INnvestigation and Growing environmental awareness) in his conception, realization and data analysis was a collaboration of Peppe with Michela Rogora and Dario Manca, both at CNR ISE, and with Walter Zerla, promoter of the initiative "Sailing on Lago Maggiore and Lago d'Orta". The connection between Peppe, Zerla and the other colleagues shines through in the photos taken during the project realization

The interactions between the impact of global climatic factors and local anthropogenic disturbances has been pursued recently in the project BLASCO (Blending Laboratory and satellite techniques for detecting cyanobacteria in lakes). Cyanobacterial blooms are increasingly observed worldwide generating preoccupation for lake trophic function and for safety of water use. This project has been considered outstanding by a panel of international referees "It is an excellent project based on a long tradition of limnological studies brought to a global level through satellite data. The findings would appeal a large community of limnologists. This research is timely because it addresses an urgent problem and promises to improve the calibration of satellite-based technologies". I had the chance, as the director of the Istituto, to follow the different stages of this Project going from the inception to its development in which Peppe collaborated with Alessandro Oggioni and Mariano Bresciani, both at IREA CNR. This research linking field methods with sophisticated laboratory techniques has already resulted in significant international publications.

BLASCO was Peppe's last project to which he dedicated all his time despite his worsening health. He succeeded to accomplish this research until the final workshop of June 15 2017, just twenty-seven days before his untimely death. This final achievement is one of his many scientific and humane legacies. I like to remember over all his particular way to be a man of science and a concerned citizen, to be profound in his research and light, never presumptuous, in the delivery of his results. These are rare virtues indeed, particularly nowadays.

Marina M. Manca Senior research associate, CNR ISE Verbania Pallanza Italy

Translated by Antonella Cattaneo Universitè de Montreal, Montreal Quebec, Canada

\section{SOME SELECTED PUBLICATIONS}

Bettinetti R, Morabito G, Provini A 2000. Phytoplankton assemblage structure and dynamics as indicator of the recent trophic and biological evolution of the western basin of Lake Como (N. Italy). Hydrobiologia 435:177-190.

Boggero A, Fontaneto D, Morabito G, Volta P, 2014. Limnology in the $21^{\text {st }}$ century: The importance of freshwater ecosystems as model systems in ecology and evolution. J. Limnol. 73:1-3.

Bresciani M, Giardino C, Lauceri R, Matta E, Cazzaniga I, Pinardi M, Lami A, Austoni M, Viaggiu E, Congestri R, Morabito G, 2016. Earth observation for monitoring and mapping of cyanobacteria blooms. Case studies on five Italian lakes. J. Limnol. 76(s1):127-139.

Bresciani M, Rossini M, Morabito G, Matta E, Pinardi M, Cogliati S, Julitta T, Colombo R, Braga F Giardino C, 2013. Analysis of within-and between-day chlorophyll- $a$ dynamics in Mantua Superior Lake, with a continuous spectroradiometric measurement. Mar. Freshwat. Res. 64:303-316.

Bresciani M, Stroppiana D, Odermatt D, Morabito G, Giardino C, 2011. Assessing remotely sensed chlorophyll-a for the implementation of the Water Framework Directive in European perialpine lakes. Sci. Total Environ. 409:3083-3091.

Callieri C, Caravati E, Morabito G, Oggioni A, 2005. The unicellular freshwater cyanobacterium Synechococcus and mixotrophic flagellates: evidence for a functional association in an oligotrophic, subalpine lake. Freshwater Biol. 51:263-273.

Callieri C, Morabito G, Huot Y, Neale PJ, Litchman E 2001. Photosynthetic response of pico- and nanoplanktonic algae to UVB, UVA and PAR in a high mountain lake. Aquat. Sci. 63:286-293.

Carvalho L, Poikane S, Lyche Solheim A, Phillips G, Borics G, Catalan J, De Hoyos C, Drakare S, Dudley BJ, Järvinen M, Laplace-Treyture C, Maileht K, McDonald C, Mischke U, Moe J, Morabito G, Nõges P, Nõges T, Ott I, Pasztaleniec A, Skjelbred B, Thackeray SJ, 2012. Strength and uncertainty of phytoplankton metrics for assessing eutrophication impacts in lakes. Hydrobiologia 704:1-14.

Cattaneo A, De Sève M, Morabito G, Mosello R, Tartari G, 2011. Periphyton changes over 20 years of chemical recovery of Lake Orta, Italy: differential response to perturbation of littoral and pelagic communities. J. Limnol. 70:177-185.

Gallina N, Salmaso N, Morabito G, Beniston M, 2013. Phytoplankton configuration in six deep lakes in the peri-Alpine region: Are the key drivers related to eutrophication and climate? Aquat. Ecol. 47:177-193.

Giardino C, Bresciani M, Stroppiana D, Oggioni A, Morabito G, 2014. Optical remote sensing of lakes: An overview on Lake Maggiore. J. Limnol. 73:210-214.

Lami, A, Tartari GA, Musazzi S, Guilizzoni P, Marchetto A, Manca M, Boggero A, Nocentini AM, Morabito G, Tartari G, Guzzella L, Bertoni R, Callieri C, 2007. 21 High altitude lakes: limnology and paleolimnology. Dev. Earth Surf. Process. 10:155-170.

Lauceri A, Bresciani M, Lami A, Morabito G, 2017. Chlorophyll $a$ interference in phycocyanin and allophycocyanin spectrophotometric quantification. J. Limnol. E-Pub 28 September 2017. doi: 10.4081/jlimnol.2017.1691

Manca M, Cavicchioni N, Morabito G 2000. First Observations 
on the effect of a complete, exceptional overturn of Lake Maggiore on plankton and primary productivity. Int. Rev. Gesamten Hydrobiol. Hydrograp. 85:209-222.

Morabito G, 2001. Six years' (1992-1997) evolution of phytoplankton communities after recovery by liming in Lake Orta, northern Italy. Lakes Reserv. Res. Manag. 6:305-312.

Morabito G, Boggero A, Galanti G, Giussani G, Oggioni A, Volta P, 2008. Problemi e prospettive per l'utilizzo delle biocenosi lacustri come indicatori di qualità ecologica ai sensi della Direttiva Comunitaria 2000/60/CE. Progetto C 51. Rapporto Finale: 99 pp.

Morabito G, Curradi M 1997. Phytoplankton community structure of a deep subalpine Italian Lake (Lake Orta, N. Italy) four years after the recovery from acidification by liming. Int. Rev. Gesamten Hydrobiol. Hydrograp. 82:487-506.

Morabito G, Oggioni A, Austoni M, 2012. Resource ratio and human impact: How diatom assemblages in Lake Maggiore responded to oligotrophication and climatic variability. Hydrobiologia 698:47-60.

Morabito G, Oggioni A, Caravati E, 2005. Decadal trends of pelagic algal biomass capacities in Lago Maggiore $(\mathrm{N}$. Italy). Verh. Internat. Verein. Limnol. 29:231-234.

Morabito G, Oggioni A, Caravati E, Panzani P, 2007. Seasonal morphological plasticity of phytoplankton in Lago Maggiore (N. Italy). Hydrobiologia 578:47-57.

Morabito G, Oggioni A, Panzani P, 2003. Phytoplankton assemblage at equilibrium in large and deep subalpine lakes: A case study from Lago Maggiore (N. Italy). Hydrobiologia 502:37-48.

Morabito G, Mazzocchi MG, Salmaso N, Zingone A Bergami C, Flaim G, Accoroni S, Basset A, Bastianini M, Belmonte G, Bernardi Aubry F, Bertani I, Bresciani M, Buzzi F, Cabrini M, Camatti E, Caroppo C, Cataletto B, Castellano M, -Del Negro P, de Olazabal A, Di Capua I, Elia AC, Fornasaro D, Giallain M, Grilli F, Leoni B, Lipizer M, Longobardi L, Ludovisi A, Lugliè A, Manca M, Margiotta F, Mariani MA, Marini M, Marzocchi M, Obertegger U, Oggioni A, Padedda BM, Pansera M, Piscia R, Povero P, Pulina S, Romagnoli T, Rosati I, Rossetti G, Rubino F, Sarno D, Satta CT, Sechi N, Stanca E, Tirelli V, Totti C, Pugnetti A, 2017. Plankton dynamics across the freshwater, transitional and marine research sites of the LTER-Italy Network. Patterns, fluctuations, drivers. Sci.Total Environ. (In press).

Morabito G, Pugnetti A 2000. Primary productivity and related variables in the course of the trophic evolution of Lake Maggiore. Int. Ver. Theor. Angewan. Limnol. Verh. 27:2934-2937.

Morabito G, Ruggiu D, Panzani P 2001. Trends of phytoplankton characteristics and their communities in pre- and postliming time in Lake Orta (1984-1998). J. Limnol. 60:91-100.

Morabito G, Ruggiu D, Panzani P, 2002. Recent dynamics (1995-1999) of the phytoplankton assemblages in Lago Maggiore as a basic tool for defining association patterns in the Italian deep lakes. J. Limnol. 61:129-145.

Morabito G, Salmaso N, Ruggiu D, 2003. Phytoplankton association patterns in the deep southern subalpine lakes (Part 2). J. Limnol. 62:75-176.

Neale PJ, Litchman E, Sobrino C, Callieri C, Morabito G, Montecino V, Huot Y, Bossard P, Lehmann C, Steiner D 2001. Quantifying the response of phytoplankton photosynthesis to ultraviolet radiation: Biological weighting functions ver- sus in situ measurements in two Swiss lakes. Aquat. Sci. 63:265-285.

Pahissa J, Catalan J, Morabito G, Dörflinger G, Ferreira J, Laplace-Treyture C, Gîrbea R, Marchetto A, Polykarpou P, de Hoyos C, 2015. Benefits and limitations of an intercalibration of phytoplankton assessment methods based on the Mediterranean GIG reservoir experience. Sci. Total Environ. 538:169-179.

Pareeth S, Bresciani M, Buzzi F, Leoni B, Lepori F, Ludovisi A, Morabito G, Adrian R, Neteler M, Salmaso N, 2017. Warming trends of perialpine lakes from homogenised time series of historical satellite and in-situ data. Sci. Total Environ. 578:417-426.

Phillips G, Lyche-Solheim A, Skjelbred B, Mischke U, Drakare S, Free G, De Hoyos MJC, Morabito G, Poikane S, Carvalho L, 2012. A phytoplankton trophic index to assess the status of lakes for the Water Framework Directive. Hydrobiologia 704: 75-85.

Pugnetti A, Camatti E, Mangoni O, Morabito G, Oggioni A, Saggiomo V, 2006. Phytoplankton production in Italian freshwater and marine ecosystems: State of the art and perspectives. Chem. Ecol. 22(s1):49-69.

Ruggiu D, Morabito G, Panzani P, Pugnetti A 1998. Trends and relations among basic phytoplankton characteristics in the course of the long-term oligotrophication of Lake Maggiore (Italy). Hydrobiologia 370: 243-257.

Salmaso N, Buzzi F, Cerasino L, Garibaldi L, Leoni B, Morabito G, Rogora M, Simona M, 2013. Influence of atmospheric modes of variability on the limnological characteristics of large lakes south of the Alps: A new emerging paradigm. Hydrobiologia 731:31-48.

Salmaso N, Morabito G, Buzzi F, Garibaldi L, Simona M, Mosello R, 2006. Phytoplankton as an Indicator of the Water Quality of the Deep Lakes South of the Alps. Hydrobiologia 563:167-187.

Salmaso N, Morabito G, Garibaldi L, Mosello R, 2007. Trophic development of the deep lakes south of the Alps: A comparative analysis. Fundam. Appl. Limnol. 170:177-196.

Salmaso N, Morabito G, Mosello R, Garibaldi L, Simona M, Buzzi F, Ruggiu D, 2003. A synoptic study of phytoplankton in the deep lakes south of the Alps (lakes Garda, Iseo, Como, Lugano and Maggiore). J. Limnol. 62:207-227.

Stefani F, Salerno F, Copetti D, Rabuffetti D, Guidetti L, Torri G, Naggi A, Iacomini M, Morabito G, Guzzella L, 2016. Endogenous origin of foams in lakes: a long-term analysis for Lake Maggiore (northern Italy). Hydrobiologia 767:249-265.

Tapolczai K, Anneville O, Padisák J, Salmaso N, Morabito G, Zohary T, Tadonléké RD, Rimet F, 2014. Occurrence and mass development of Mougeotia spp. (Zygnemataceae) in large, deep lakes. Hydrobiologia 745:17-29.

Taranu ZE, Gregory-Eaves I, Leavitt PR, Bunting L, Buchaca T, Catalan J, Domaizon I, Guilizzoni P, Lami A, McGowan S, Moorhouse H, Morabito G, Pick FR, Stevenson MA, Thompson PL, Vinebrooke RD, 2015. Acceleration of cyanobacterial dominance in north temperate-subarctic lakes during the Anthropocene. Ecol. Lett. 18:375-384.

Tessier C, Cattaneo A, Pinel-Alloul B, Galanti G, Morabito G, 2004. Biomass, composition and size structure of invertebrate communities associated to different types of aquatic vegetation during summer in Lago di Candia (Italy). 63:190-198. 
Thackeray SJ, Nõges P, Dunbar MJ, Birger Skjelbred BJD, Morabito G, Carvalho L, Phillips G, Mischke U, Catalan J, de Hoyos C, Laplace C, Austoni M, Padedda BM, Maileht K, Pasztaleniec A, Järvinen M, Lyche Solheim A, Clarke RT, 2013. Quantifying uncertainties in biologically-based water quality assessment: A pan-European analysis of lake phytoplankton community metrics. Ecol. Indic. 29:34-47.

Tiberti R, Metta S, Austoni M, Callieri C, Morabito G, Marchetto A, Rogora M, Tartari GA, Von Hardenberg J, Provenzale A, 2013. Ecological dynamics of two remote Alpine lakes during ice-free season. J. limnol. 72:401-416.

Tolotti M, Forsström L, Morabito G, Thaler B, Stoyneva M, Cantonati M, Šiško M, Lotter AF, 2009. Biogeographical characterisation of phytoplankton assemblages in high altitude, and high latitude European lakes. Adv. Limnol. 62:55-75.

Tolotti M, Manca M, Angeli N, Morabito G, Thaler B, Rott E, Stuchlik E 2006. Phytoplankton and zooplankton associa- tions in a set of alpine high altitude lakes: Geographic distribution and ecology. Hydrobiologia 562:99-122.

Trevisan R, Picarella M, Dazzo FB, Bona S, Morabito G, Squartini A, 2014. Using a Morpho-Functional approach to assess phytoplankton dynamics in two adjacent high-mountain lakes: A 10-year survey. J. Limnol. 73:409-420.

Wolfram G, Argillier C, de Bortoli J, Buzzi F, Dalmiglio A, Dokulil MT, Hoehn E, Marchetto A, Martinez P-J, Morabito G, Reichmann MS, Remec-Rekar Š, Riedmüller U, Rioury C, Schaumburg J, Schulz L, Urbanič G, 2009. Reference conditions and WFD compliant class boundaries for phytoplankton biomass and chlorophyll- $a$ in Alpine lakes. Hydrobiologia 33:45-58.

More at

https://scholar.google.it/citations?user=qzxlU0MAAAAJ\&hl=it 